\title{
Frequency of Genetic Mutations Associated with Thromboembolism in the Western Black Sea Region
}

\author{
Esra Tug, Hatip Aydin, Ebru Kaplan and Dilek Dogruer
}

\begin{abstract}
Objective We aimed to determine the prevalences of important genetic causes of thromboembolism for the first time in the western Black Sea Region of Turkey.

Patients and Methods One hundred and eighty-eight patients diagnosed early with thrombophilia were included in the study. The samples were genotyped using real-time LightCycler.

Results Of the 188 patients, $179(95.2 \%)$ had one or more mutations. The frequencies of Factor V (FV) Leiden (FVL, G1691A), FV H1299R (A1299G), Factor II (FII G20210A), methylenetetrahydrofolate reductase (MTHFR) C677T and A1298C were 11.7\%, 5.6\%, 2.5\%, 30.4\% and 39.1\%, respectively. FV1691A was commonly represented in deep venous thrombosis (34.2\%). The highest frequencies of FV1299G and FII20210A were in the vascular headache and deep venous thrombosis groups $(10 \%$ and $10.5 \%$, respectively). MTHFR677T was common in the pulmonary embolism (37\%). MTHFR1298C frequency was 55.9\% in recurrent abortus. Within-group comparisons yielded significant differences in the distributions of the FVL and FV H1299R mutations ( $\mathrm{p}=0.002$ and $\mathrm{p}=0.039$, respectively).

Conclusion There were significant positive associations between venous thromboembolism and FVL and FV H1299R. FVL mutation in DVT may be an important predisposing factor that needs to be tested routinely in this population.
\end{abstract}

Key words: thromboembolism-factor V gene-prothrombin gene-methylene tetrahydrofolate reductase genegenetic mutation

(Intern Med 50: 17-21, 2011)

(DOI: 10.2169/internalmedicine.50.4144)

\section{Introduction}

Venous thromboembolism is a major medical problem, affecting 1 to 5 individuals per 1,000 annually $(1,2)$. In the past 50 years, the molecular bases of both blood coagulation and the anticoagulant pathways have been explained, and several genetic risk factors for venous thrombosis have been identified. These genetic risk factors affect the natural anticoagulant mechanisms and result in a hypercoagulable state due to an imbalance between procoagulant and anticoagulant forces. Thrombosis is a lifelong risk, and thrombotic events tend to occur when one or more of the circumstantial risk factors come into play. It is a typical multifactorial disease, with the pathogenesis involving both environmental and genetic mechanisms (1).
The three most common genetic thrombophilias known to predispose to venous thrombosis are Factor V Leiden mutation (FVL, G1691A), methylenetetrahydrofolate reductase mutation (MTHFR) and prothrombin gene mutation (FII). In FVL, arginine is substituted by glutamine at amino acid residue in 506 coagulation factor V. Due to this substitution, factor Va becomes resistant to degradation by activated protein $\mathrm{C}$, resulting in a 3 - to 5-fold increase in the risk of venous thromboembolism in heterozygous individuals (3). Another risk factor in factor V gene is FV H1299R (4). In FII G20210A, a G to A transition at position 20,210 of the 3' untranslated region of the factor II gene has been found to be associated with increased prothrombin level and a 3-fold increase in the risk for venous thrombosis in heterozygotes. The homozygous state for the $\mathrm{C}$ to $\mathrm{T}$ transition at position 677 of MTHFR gene is associated with hyperhomocysteine- 
Table 1. The Frequencies of Patient Groups and Allelic Distributions of the Groups

\begin{tabular}{|c|c|c|c|c|c|c|c|c|}
\hline & & $\begin{array}{c}P E \\
14.3 \% \\
(n=27)\end{array}$ & $\begin{array}{c}\text { CVD } \\
14.3 \% \\
(n=27)\end{array}$ & $\begin{array}{c}\text { DVT } \\
10.1 \% \\
(n=19)\end{array}$ & $\begin{array}{c}\text { headache }^{\dagger} \\
11.1 \% \\
(n=21)\end{array}$ & $\begin{array}{c}\text { AF } \\
8.5 \% \\
(n=16)\end{array}$ & $\begin{array}{c}\text { RA } \\
9 \% \\
(n=17)\end{array}$ & Total \\
\hline \multirow[t]{2}{*}{ FV Leiden ${ }^{a}$} & $\begin{array}{l}\text { G } \\
\text { allele }\end{array}$ & $\begin{array}{c}81.48 \% \\
(n=44)\end{array}$ & $\begin{array}{l}\% 96.3 \\
(n=52)\end{array}$ & $\begin{array}{l}65.7 \% \\
(n=25)\end{array}$ & $\begin{array}{c}95 \% \\
(n=38)\end{array}$ & $\begin{array}{l}96.9 \% \\
(n=31)\end{array}$ & $\begin{array}{l}94.1 \% \\
(n=32)\end{array}$ & $\begin{array}{l}88.24 \% \\
(n=222)\end{array}$ \\
\hline & $\begin{array}{l}\text { A } \\
\text { allele }\end{array}$ & $\begin{array}{l}18.5 \% \\
(n=10)\end{array}$ & $\begin{array}{l}3.7 \% \\
(n=2)\end{array}$ & $\begin{array}{l}34.2 \% \\
(\mathrm{n}=13)\end{array}$ & $\begin{array}{c}5 \% \\
(n=2)\end{array}$ & $\begin{array}{l}3.1 \% \\
(\mathrm{n}=1)\end{array}$ & $\begin{array}{l}5.9 \% \\
(\mathrm{n}=2)\end{array}$ & $\begin{array}{c}11.73 \% \\
(n=30)\end{array}$ \\
\hline \multirow[t]{2}{*}{ FV $1299^{b}$} & $\begin{array}{l}\text { A } \\
\text { allele }\end{array}$ & $\begin{array}{l}100 \% \\
(\mathrm{n}=54)\end{array}$ & $\begin{array}{l}98.1 \% \\
(n=53)\end{array}$ & $\begin{array}{l}97.4 \% \\
(n=37)\end{array}$ & $\begin{array}{c}90 \% \\
(n=36)\end{array}$ & $\begin{array}{l}96.9 \% \\
(n=31)\end{array}$ & $\begin{array}{l}90.6 \% \\
(n=29)\end{array}$ & $\begin{array}{c}95.5 \% \\
(n=240)\end{array}$ \\
\hline & $\begin{array}{l}\text { G } \\
\text { allele }\end{array}$ & $\begin{array}{c}- \\
(\mathrm{n}=0)\end{array}$ & $\begin{array}{l}1.9 \% \\
(\mathrm{n}=1)\end{array}$ & $\begin{array}{l}2.6 \% \\
(\mathrm{n}=1)\end{array}$ & $\begin{array}{l}10 \% \\
(n=4)\end{array}$ & $\begin{array}{l}3.1 \% \\
(\mathrm{n}=1)\end{array}$ & $\begin{array}{l}9.4 \% \\
(\mathrm{n}=3)\end{array}$ & $\begin{array}{c}4.5 \% \\
(n=10)\end{array}$ \\
\hline \multirow[t]{2}{*}{ FII $^{c}$} & $\begin{array}{l}\text { G } \\
\text { allele }\end{array}$ & $\begin{array}{l}100 \% \\
(\mathrm{n}=54)\end{array}$ & $\begin{array}{l}98.1 \% \\
(n=53)\end{array}$ & $\begin{array}{l}89.5 \% \\
(\mathrm{n}=34)\end{array}$ & $\begin{array}{l}100 \% \\
(n=40)\end{array}$ & $\begin{array}{l}93.8 \% \\
(\mathrm{n}=30)\end{array}$ & $\begin{array}{c}97 \% \\
(n=33)\end{array}$ & $\begin{array}{c}96.4 \% \\
(n=244)\end{array}$ \\
\hline & $\begin{array}{l}\text { A } \\
\text { allele }\end{array}$ & $\begin{array}{c}- \\
(\mathrm{n}=0)\end{array}$ & $\begin{array}{l}1.9 \% \\
(\mathrm{n}=1)\end{array}$ & $\begin{array}{l}10.5 \% \\
(n=4)\end{array}$ & $\begin{array}{c}- \\
(\mathrm{n}=0)\end{array}$ & $\begin{array}{l}6.2 \% \\
(\mathrm{n}=2)\end{array}$ & $\begin{array}{c}3 \% \\
(\mathrm{n}=1)\end{array}$ & $\begin{array}{l}3.6 \% \\
(\mathrm{n}=8)\end{array}$ \\
\hline \multirow[t]{2}{*}{ MTHFR $677^{d}$} & $\begin{array}{l}\mathrm{C} \\
\text { allele }\end{array}$ & $\begin{array}{c}63 \% \\
(n=34)\end{array}$ & $\begin{array}{l}68.5 \% \\
(n=37)\end{array}$ & $\begin{array}{l}76.3 \% \\
(n=29)\end{array}$ & $\begin{array}{l}78.6 \% \\
(n=33)\end{array}$ & $\begin{array}{l}65.6 \% \\
(\mathrm{n}=21)\end{array}$ & $\begin{array}{l}73.5 \% \\
(n=25)\end{array}$ & $\begin{array}{c}71 \% \\
(n=179)\end{array}$ \\
\hline & $\begin{array}{l}\mathbf{T} \\
\text { allele }\end{array}$ & $\begin{array}{c}37 \% \\
(\mathrm{n}=20)\end{array}$ & $\begin{array}{l}31.5 \% \\
(n=17)\end{array}$ & $\begin{array}{c}23.7 \% \\
(\mathrm{n}=9)\end{array}$ & $\begin{array}{c}21.4 \% \\
(n=9)\end{array}$ & $\begin{array}{l}34.4 \% \\
(\mathrm{n}=11)\end{array}$ & $\begin{array}{l}26.5 \% \\
(n=9)\end{array}$ & $\begin{array}{c}29 \% \\
(\mathrm{n}=75)\end{array}$ \\
\hline \multirow[t]{2}{*}{ MTHFR $1298^{\mathrm{e}}$} & $\begin{array}{l}\text { A } \\
\text { allele }\end{array}$ & $\begin{array}{l}61.1 \% \\
(n=33)\end{array}$ & $\begin{array}{l}57.4 \% \\
(\mathrm{n}=31)\end{array}$ & $\begin{array}{l}60.5 \% \\
(n=23)\end{array}$ & $\begin{array}{c}50 \% \\
(n=21)\end{array}$ & $\begin{array}{l}62.5 \% \\
(n=20)\end{array}$ & $\begin{array}{l}44.1 \% \\
(n=15)\end{array}$ & $\begin{array}{c}56 \% \\
(n=143)\end{array}$ \\
\hline & $\begin{array}{l}\mathrm{C} \\
\text { allele }\end{array}$ & $\begin{array}{l}38.9 \% \\
(n=21)\end{array}$ & $\begin{array}{l}42.6 \% \\
(n=23)\end{array}$ & $\begin{array}{l}39.5 \% \\
(n=15)\end{array}$ & $\begin{array}{c}50 \% \\
(\mathrm{n}=21)\end{array}$ & $\begin{array}{l}37.5 \% \\
(n=12)\end{array}$ & $\begin{array}{l}55.9 \% \\
(\mathrm{n}=19)\end{array}$ & $\begin{array}{c}44 \% \\
(n=111)\end{array}$ \\
\hline
\end{tabular}

PE: pulmonary embolism; CVD: cerebrovascular disease; DVT: deep venous thrombosis; ${ }^{\dagger}$ vascular headache; AF: amurosis fugacs; RA: recurrent abortus; a: factor V G1691A mutation; b; factor V H1299R mutation; c: prothrombin factor II G20210A mutation; d: methylenetetrahydrofolate reductase C677T mutation; e: methylenetetrahydrofolate reductase $\mathbf{A 1 2 9 8 C}$ mutation.

mia which predisposes to thrombosis (3). Another risk factor in MTHFR gene is known as A1298C mutation (4).

FVL, FII G20210A and MTHFR C677T mutations are currently the most common known genetic risk factors for venous thrombosis among Caucasians (5). We aimed to determine the prevalences of important genetic causes of thromboembolism for the first time in the Western Black Sea Region of Turkey.

\section{Material and Methods}

\section{l. Patients}

The important risk factors for thromboembolism were studied on a total of 127 patients with early thrombophilia, 86 females (mean age $44 \pm 15.32$ ) and 41 males (mean age $51 \pm 17.46$ ), referred to our clinic from various departments between September 2008-May 2009. Written informed consents were obtained from all participants. When grouped by their diagnosis, patients were allocated into one of six groups, namely deep venous thrombosis (DVT) $(n=19)$, pulmonary embolism (PE) $(n=27)$, cerebrovascular disease (CVD) $(n=27)$, vascular headache $(n=21)$, amurosis fugacs (AF) $(n=16)$ and recurrent abortus (RA) $(n=17)$.

\section{Diagnostic techniques}

Genomic DNA was isolated from the peripheral blood samples using QIAamp DNA Blood Mini Kit (Qiagen, Germany). To determine the genetic risk factors for thrombophilia, the subjects were genotyped for FVL, FV H1299R, FII G20210A, C677T and A1298C of MTHFR mutations by PCR with Rotor Gene 6000 LightCycler (Corbett Life Sci- ence, Concorde, NSW) according to the guidelines of the manufacturer.

\section{Statistical analysis}

Allele frequencies were determined by gene counting. The frequencies of the alleles, respective $95 \%$ confidence intervals (CI) and genotypes among patients were determined and compared by the chi square $\left(\mathrm{X}^{2}\right)$ test know that the population meets Hardy-Weinberg equilibrium assumptions. Statistical significance was set at $\mathrm{p}<0.05$.

\section{Results}

The frequencies of the patient groups and allelic distribution in each group are presented in Table 1; 34.3\% of the first degree relatives and $5.1 \%$ of the second degree relatives of the patients had thromboembolic disorder which was diagnosed clinically. Of the 188 patients, 179 (95.2\%) of the patients had one or more mutations. FV1691A was most commonly represented in DVT (34.2\%), followed by PE (18.5\%). The highest frequency of FV1299 G was observed in the vascular headache $(10 \%)$, followed by the RA $(9.4 \%)$. FII20210A was most common in the DVT (10.5\%), followed by the AF (6.2\%). MTHFR677T, on the other hand, was the most common mutation in the PE (37\%), followed by the AF (34.4\%). MTHFR1298C frequency was highest in the RA $(55.9 \%)$, followed by the vascular headache $(50 \%)$. When the results were analyzed with respect to the patient groups, statistically significant differences were found in the percentage distributions of FVL and FV H1299R ( $p=0.002$ and $\mathrm{p}=0.039$, respectively). On the other hand, there were no statistically significant differences in the percentage dis- 
Table 2. Genotypic Distribution for Patient Groups

\begin{tabular}{|c|c|c|c|c|c|c|c|c|}
\hline & & PE & CVD & DVT & headache $\dagger$ & $\mathbf{A F}$ & $\mathbf{R A}$ & Total \\
\hline \multirow[t]{3}{*}{ FV Leiden ${ }^{a}$} & wild & $\begin{array}{l}66.6 \% \\
(n=18)\end{array}$ & $\begin{array}{l}92.6 \% \\
(\mathrm{n}=25)\end{array}$ & $\begin{array}{l}52.6 \% \\
(\mathrm{n}=10)\end{array}$ & $\begin{array}{c}90 \% \\
(\mathrm{n}=18)\end{array}$ & $\begin{array}{l}93.75 \% \\
(n=15)\end{array}$ & $\begin{array}{l}88.2 \% \\
(\mathrm{n}=15)\end{array}$ & $\begin{array}{c}80.7 \% \\
(n=101)\end{array}$ \\
\hline & heterozygote & $\begin{array}{c}29.7 \% \\
(\mathrm{n}=8)\end{array}$ & $\begin{array}{l}7.4 \% \\
(\mathrm{n}=2)\end{array}$ & $\begin{array}{l}26.3 \% \\
(n=5)\end{array}$ & $\begin{array}{l}10 \% \\
(\mathrm{n}=2)\end{array}$ & $\begin{array}{c}6.25 \% \\
(\mathrm{n}=1)\end{array}$ & $\begin{array}{l}11.8 \% \\
(\mathrm{n}=2)\end{array}$ & $\begin{array}{l}15.2 \% \\
(\mathrm{n}=20)\end{array}$ \\
\hline & homozygote & $\begin{array}{l}3.7 \% \\
(n=1)\end{array}$ & $\begin{array}{c}- \\
(n=0)\end{array}$ & $\begin{array}{l}21 \% \\
(n=4)\end{array}$ & $\begin{array}{c}- \\
(\mathrm{n}=0)\end{array}$ & $\begin{array}{c}- \\
(n=0)\end{array}$ & $\begin{array}{c}- \\
(n=0)\end{array}$ & $\begin{array}{l}4.1 \% \\
(n=5)\end{array}$ \\
\hline \multirow{2}{*}{ FV $1299^{b}$} & heterozygote & $\begin{array}{c}- \\
(\mathrm{n}=0)\end{array}$ & $\begin{array}{l}3.7 \% \\
(\mathrm{n}=1)\end{array}$ & $\begin{array}{l}5.3 \% \\
(n=1)\end{array}$ & $\begin{array}{l}20 \% \\
(n=4)\end{array}$ & $\begin{array}{c}6.25 \% \\
(n=1)\end{array}$ & $\begin{array}{l}6.25 \% \\
(n=1)\end{array}$ & $\begin{array}{c}7 \% \\
(\mathrm{n}=8)\end{array}$ \\
\hline & homozygote & $\begin{array}{c}- \\
(\mathrm{n}=0)\end{array}$ & $\begin{array}{c}- \\
(\mathrm{n}=0)\end{array}$ & $\begin{array}{c}- \\
(\mathrm{n}=0)\end{array}$ & $\begin{array}{c}- \\
(\mathrm{n}=0)\end{array}$ & $\begin{array}{c}- \\
(\mathrm{n}=0)\end{array}$ & $\begin{array}{l}6.25 \% \\
(\mathrm{n}=1)\end{array}$ & $\begin{array}{c}1 \% \\
(\mathrm{n}=1)\end{array}$ \\
\hline \multirow[t]{2}{*}{ FII $^{c}$} & wild & $\begin{array}{l}100 \% \\
(\mathrm{n}=27)\end{array}$ & $\begin{array}{l}96.3 \% \\
(n=26)\end{array}$ & $\begin{array}{l}84.1 \% \\
(n=16)\end{array}$ & $\begin{array}{c}100 \% \\
(n=20)\end{array}$ & $\begin{array}{l}87.5 \% \\
(n=14)\end{array}$ & $\begin{array}{l}94.1 \% \\
(n=16)\end{array}$ & $\begin{array}{c}93.6 \% \\
(n=119)\end{array}$ \\
\hline & homozygote & $\begin{array}{c}- \\
(n=0)\end{array}$ & $\begin{array}{c}- \\
(n=0)\end{array}$ & $\begin{array}{l}5.3 \% \\
(n=1)\end{array}$ & $\begin{array}{c}- \\
(n=0)\end{array}$ & $\begin{array}{c}- \\
(n=0)\end{array}$ & $\begin{array}{c}- \\
(n=0)\end{array}$ & $\begin{array}{l}0.9 \% \\
(n=1)\end{array}$ \\
\hline \multirow[t]{3}{*}{$\begin{array}{l}\text { MTHFR } \\
677^{d}\end{array}$} & wild & $\begin{array}{c}33.2 \% \\
(\mathrm{n}=9)\end{array}$ & $\begin{array}{l}48.1 \% \\
(n=13)\end{array}$ & $\begin{array}{l}64.1 \% \\
(n=12)\end{array}$ & $\begin{array}{l}61.9 \% \\
(n=13)\end{array}$ & $\begin{array}{c}37.5 \% \\
(\mathrm{n}=6)\end{array}$ & $\begin{array}{l}58.8 \% \\
(\mathrm{n}=10)\end{array}$ & $\begin{array}{c}51 \% \\
(n=63)\end{array}$ \\
\hline & heterozygote & $\begin{array}{l}59.3 \% \\
(n=16)\end{array}$ & $\begin{array}{l}40.7 \% \\
(n=11)\end{array}$ & $\begin{array}{c}26.3 \% \\
(n=5)\end{array}$ & $\begin{array}{c}33.3 \% \\
(n=7)\end{array}$ & $\begin{array}{l}66.7 \% \\
(\mathrm{n}=9)\end{array}$ & $\begin{array}{c}29.4 \% \\
(n=5)\end{array}$ & $\begin{array}{l}40.4 \% \\
(n=53)\end{array}$ \\
\hline & homozygote & $\begin{array}{l}7.4 \% \\
(n=2)\end{array}$ & $\begin{array}{l}11.2 \% \\
(\mathrm{n}=3)\end{array}$ & $\begin{array}{l}10.6 \% \\
(n=2)\end{array}$ & $\begin{array}{l}4.8 \% \\
(n=1)\end{array}$ & $\begin{array}{l}6.25 \% \\
(n=1)\end{array}$ & $\begin{array}{l}11.8 \% \\
(n=2)\end{array}$ & $\begin{array}{c}8.6 \% \\
(n=11)\end{array}$ \\
\hline \multirow[t]{2}{*}{$\begin{array}{l}\text { MTHFR } \\
1298^{\mathrm{e}}\end{array}$} & wild & $\begin{array}{l}33.2 \% \\
(\mathrm{n}=9)\end{array}$ & $\begin{array}{c}29.7 \% \\
(\mathrm{n}=8)\end{array}$ & $\begin{array}{l}42 \% \\
(n=8)\end{array}$ & $\begin{array}{c}33.3 \% \\
(n=7)\end{array}$ & $\begin{array}{c}44.25 \% \\
(n=7)\end{array}$ & $\begin{array}{l}29.4 \% \\
(n=5)\end{array}$ & $\begin{array}{l}34.3 \% \\
(\mathrm{n}=44)\end{array}$ \\
\hline & heterozygote & $\begin{array}{l}55.6 \% \\
(\mathrm{n}=15)\end{array}$ & $\begin{array}{l}55.5 \% \\
(n=15)\end{array}$ & $\begin{array}{c}36.9 \% \\
(n=7)\end{array}$ & $\begin{array}{c}33.3 \% \\
(n=7)\end{array}$ & $\begin{array}{l}37.5 \% \\
(n=6)\end{array}$ & $\begin{array}{l}29.4 \% \\
(n=5)\end{array}$ & $\begin{array}{l}40.7 \% \\
(n=55)\end{array}$ \\
\hline
\end{tabular}

PE: pulmonary embolism; CVD: cerebrovascular disease; DVT: deep venous thrombosis; $\uparrow$ : vascular headache; $\overline{\text { AF: amurosis }}$ fugacs; RA: recurrent abortus; a: factor V G1691A mutation; b; factor V H1299R mutation; c: prothrombin factor II G20210A mutation; d: methylenetetrahydrofolate reductase C677T mutation; e: methylenetetrahydrofolate reductase A1298C mutation.

tributions of FII, MTHFR C677T and MTHFR A1298C mutations between groups $(\mathrm{p}=0.159, \mathrm{p}=0.443$ and $\mathrm{p}=0.098$, respectively).

Genotypic distributions of the patient groups are shown in Table 2. When the distributions of the mutations in the patient groups were examined, we found that FVL heterozygous mutation was most common in the PE and DVT (29.7\% and $26.3 \%$, respectively). Moreover, the frequencies of homozygous mutation were $21 \%$ and $3.7 \%$ in the DVT and $\mathrm{PE}$, respectively. In the vascular headache, the frequency of heterozygous FV H1299R mutation was 20\% and there was no homozygous patient. Among all of the patient groups, homozygous genotype for this mutation was present in only one patient in the RA. With regard to the FII G20210A mutation, the ratios of heterozygosity in the DVT and $\mathrm{AF}$ groups were $10.6 \%$ and $12.5 \%$, respectively, and there was a single case of homogeneous genotype in the DVT $(5.3 \%)$.

With overall ratios of $40.7 \%$ and $40.4 \%$, MTHFR A1298C and C677T were the most common carrier-states in all patient groups. The frequency of homozygous $1298 \mathrm{C}$ genotype was $51.2 \%$ in the RA and $33.3 \%$ in the vascular headache. The frequency of homozygous 677T genotype was $11.8 \%, 11.2 \%$ and $10.6 \%$ in the RA, CVD and DVT, respectively. The distribution of more than one mutation with regard to the patient groups are presented in Table 3.

\section{Discussion}

Genetic risk factor assessment has become an integral component of the diagnostic evaluation of patients who present with the signs and symptoms of venous thrombosis (5). Thrombophilia is caused by a set of acquired and inherited conditions which confers a tendency to thrombus formation (6). In the present study, we investigated in 6 groups of patients arranged according to their clinical diagnoses the frequencies of five mutation regions that are important in the etiology of and co-exist significantly with thrombophilia. Moreover, we determined the number of patients with three or more mutations in each group.

The prevalence of FVL, which is one of the frequently observed and important risk factors for genetic thrombophilia, in different populations varies and the differences in distribution can be explained by ethnicity and geographic differences $(1,7)$. Its prevalence is around 3-5\% (occasionally up to $15 \%$ in certain areas) in European countries, $14 \%$ in Greece, and between $7.1-10.3 \%$ in Turkey (8-11). Though the incidence is also higher in North America, no mutations have been detected in China, Japan, Africa or Native Americans (Indians) (12). We found that prevalence of FVL in our region was $11.7 \%$, which is slightly higher than threshold value for the normal population in Turkey. 
Table 3. The Distribution of Mutations in Patients with Multiple Mutations in All 6 Patient Groups

\begin{tabular}{|c|c|c|c|c|c|c|}
\hline Groups & Patients* & FV Leiden ${ }^{a}$ & FV $1299^{b}$ & FII $^{\mathrm{c}}$ & MTHFR $677^{\mathrm{d}}$ & MTHFR $1298^{\mathrm{e}}$ \\
\hline & 1 & heterozygous & & & & homozygous \\
\hline PE & 1 & heterozygous & & & homozygous & \\
\hline$(n=6)$ & 1 & homozygous & & & heterozygous & heterozygous \\
\hline & 3 & heterozygous & & & heterozygous & heterozygous \\
\hline CVD & 2 & & & & heterozygous & homozygous \\
\hline$(n=3)$ & 1 & & & heterozygous & homozygous & \\
\hline & 3 & homozygous & & & heterozygous & \\
\hline DVT & 1 & homozygous & & heterozygous & & \\
\hline$(n=6)$ & 1 & & & heterozygous & homozygous & \\
\hline & 1 & homozygous & & homozygous & & heterozygous \\
\hline $\begin{array}{l}\text { Headache }^{\dagger} \\
(n=4)\end{array}$ & $\begin{array}{l}2 \\
1 \\
1\end{array}$ & heterozygous & $\begin{array}{l}\text { heterozygous } \\
\text { heterozygous }\end{array}$ & & heterozygous & $\begin{array}{l}\text { homozygous } \\
\text { homozygous } \\
\text { heterozygous }\end{array}$ \\
\hline $\begin{array}{l}\text { AF } \\
(n=2)\end{array}$ & $\begin{array}{l}1 \\
1 \\
1 \\
2\end{array}$ & $\begin{array}{l}\text { heterozygous } \\
\text { heterozygous }\end{array}$ & heterozygous & heterozygous & $\begin{array}{l}\text { heterozygous } \\
\text { heterozygous } \\
\text { homozygous }\end{array}$ & $\begin{array}{l}\text { heterozygous } \\
\text { heterozygous }\end{array}$ \\
\hline $\begin{array}{l}\text { RA } \\
(n=5)\end{array}$ & $\begin{array}{l}1 \\
1 \\
1\end{array}$ & & $\begin{array}{l}\text { homozygous } \\
\text { heterozygous }\end{array}$ & heterozygous & heterozygous & $\begin{array}{l}\text { homozygous } \\
\text { heterozygous } \\
\text { heterozygous }\end{array}$ \\
\hline
\end{tabular}

PE: pulmonary embolism; CVD: cerebrovascular disease; DVT: deep venous thrombosis; ${ }^{\dagger}$ : vascular headache; AF: amurosis fugacs; RA: recurrent abortus; *: Number of patients; a: factor V G1691A mutation; b; factor V H1299R mutation; c: prothrombin factor II G20210A mutation; d: methylenetetrahydrofolate reductase C677T mutation; e: methylenetetrahydrofolate reductase A1298C mutation.

Heterozygosity for FVL yields a lifelong hypercoagulable state associated with some 5 -fold increased risk of venous thrombosis, the risk being considerably higher (approximately 50 -fold) among homozygotes $(13,14)$. The present results yielded significant positive associations between venous thromboembolism and FVL and FV H1299R. Especially, FVL mutation was important in DVT with a $34.2 \%$ frequency rate and in PE with an $18.5 \%$ frequency rate.

In patients with a history of DVT, the prevalence of FVL mutation in the heterozygous state was found as $37.5 \%$ by Gul et al (15). Akar et al (9), on the other hand, reported that the prevalence of FVL mutation in thrombosis cases was $9.8 \%$. The prevalence of homozygous FVL of $21 \%$ that we found in our DVT group suggests a strong concomitance of FVL mutation especially with DVT. Further, FVL mutation in the DVT group was accompanied by MTHFR C677T, A1298C or FII G20210A mutations (Table 3). This was considered clinically very significant, indicating a marked increase in risk.

FII G20210A mutation, a risk factor for venous thrombosis, is associated with a hypercoagulable state and a lifelong 3- to 4-fold increase in the risk of venous thrombosis (14). The mutation is found in $2-4 \%$ of healthy individuals in Southern Europe. In Western societies, the mutation is found in $6-8 \%$ of patients with venous thrombosis (16). Akar et al (17) reported that the frequency of FII20210A mutation was $2.7 \%$ in Turkish population, expecting that 1 in every 400-500 healthy individuals would carry both FVL and FII G20210A mutations. In our patient population, the frequency of FII20210A, an important predisposing factor for DVT and AF, was $2.5 \%$ and this is comparable to the results of Akar et al (17). Further, concomitance of FII G20210A mutation with other genetic thrombophilia in the CVD, DVT, AF and RA groups was noteworthy (Table 3). Previous studies reported a 2- to 3-fold increase in the risk of recurrent miscarriage with FII G20210A mutation (7). In the present study, heterozygosity ratio of FII G20210A mutation of $5.9 \%$ in the RA group is comparable to $5.37 \%$ that was reported by Ozmen et al (7). However, in our study, with a 5.3\% ratio, determination of FII G20210A mutation in the homozygous state only in the DVT group but not in other groups may be of clinical significance.

A common mutation in MTHFR, C677T has been shown to increase plasma homocysteine levels and, thus cause a predisposition to thrombosis (18). The frequency of MTHFR gene mutations found in the present study was lower than that found by Ozmen et al (7). Furthermore, we found that the frequencies of MTHFR677T in the PE and 1298C in the RA groups were $37 \%$ and $55.9 \%$, respectively. These were the highest frequencies observed in groups for genetic thrombophilia. Sotiriadis et al (19) and Ozmen et al (7) argued that co-existence of FVL, FV H1299R, FII G20210A, MTHFR C677T and A1298C mutations was not related to recurrent miscarriages. In the present study, we noted multiple co-existences of C677T and A1298C mutations of MTHFR with FVL, FV H1299R and FII G20210A mutations (Table 3).

In the light of this data, we recommend probing for predisposing genetic risk factors in patients with thromboembolic complications such as DVT, PE, CVD, vascular headache, AF and RA. Clinical presentations of patients with arterial or venous thrombosis vary significantly and, with a few exceptions, the etiology of thrombus formation in either segment of the circulation is distinctly different. There are also significant differences between the venous and arterial systems with regard to the pathology of blood clots. Arterial thrombosis generally develops as a result of underlying vascular abnormalities, typically atherosclerotic vascular disease and less frequently in individuals with vasculitis. Venous thrombosis, on the other hand, usually occurs incidentally in individuals with genetic abnormalities associated with hypercoagulability. Meanwhile, Factor V, prothrombin and 
MTHFR gene mutations have been found linked to both arterial and venous thrombosis (20-23).

The distribution of the mutations among the residents of the Western Black Sea region is, for the first time, established to be similar with other parts of Turkey. Moreover, this is one of the few studies that investigated the hereditary thrombophilia parameters in patients with thromboembolism such as PE, DVT, CVD and RA as well as in patients with disorders that present with different clinical features such as vascular headache and AF. Based on the results of the present and previous studies, a careful examination for these genetic variants should be included in thrombophilia screening programs, particularly in Turkish population. Indeed, a meticulous examination of genetic causes of thromboembolism needs to be carried out for accurate diagnosis, effective treatment, and better prognosis with less mortality and morbidity. Moreover, since some inherited abnormalities are associated with thromboembolic disorders, determining the mutations and gene-to-gene interactions in patients with a history of thrombosis would have a great impact on the diagnosis and treatment of these diseases.

\section{The authors state that they have no Conflict of Interest (COI).}

\section{References}

1. Dahlbäck B. Advances in understanding pathogenic mechanisms of thrombophilic disorders. Blood 112: 19-27, 2008.

2. März W, Nauck M, Wieland H. The molecular mechanisms of inherited thrombophilia. Z Kardiol 89: 575-586, 2000.

3. Carp H, Salomon O, Seidman D, Dardik R, Rosenberg N, Inbal A. Prevalence of genetic markers for thrombophilia in recurrent pregnancy loss. Hum Reprod 17: 1633-1637, 2002.

4. Coulam CB, Wallis D, Weinstein J, DasGupta DS, Jeyendran RS. Comparison of thrombophilic gene mutations among patients experiencing recurrent miscarriage and deep vein thrombosis. Am J Reprod Immunol 60: 426-431, 2008.

5. Koksal V, Baris I, Etlik O. Primer-engineered multiplex PCRRFLP for detection of MTHFR C677T, prothrombin G20210A and factor V Leiden mutations. Exp Mol Pathol 83: 1-3, 2007.

6. Taymaz H, Erarslan S, Oner ET, Alkan T, Agirbasli M, Kirdar B. Sequence variations within the genes related to hemostatic imbalance and their impact on coronary artery disease in Turkish population. Thromb Res 119: 55-62, 2007.

7. Ozmen F, Ozmen MM, Ozalp N, Akar N. The prevalence of factor V (G1691A), MTHFR (C677T) and PT (G20210A) gene mutations in arterial thrombosis. Ulus Travma Acil Cerrahi Derg (Turkish J Trauma \& Emergency Surgery) 15: 113-119, 2009.

8. Gurgey A, Mesci L, Renda Y, Olcay L, Kocak N, Erdem G. Fac- tor V Q 506 mutation in children with thrombosis. Am J Hematol 53: 37-39, 1996.

9. Akar N, Akar E, Dalgin G, Sözüöz A, Omürlü K, Cin S. Frequency of Factor V (1691 G $\rightarrow$ A) mutation in Turkish population. Thromb Haemost 78: 1527-1528, 1997.

10. Segers K, Dahlback B, Nicolaes GA. Coagulation factor V and thrombophilia: background and mechanisms. Thromb Haemost 98 : 530-542, 2007.

11. Rees DC, Cox M, Clegg JB. World distribution of factor V Leiden. Lancet 346: 1133-1134, 1995.

12. Beauchamp NJ, Daly ME, Hampton KK, Cooper PC, Preston FE, Peake IR. High prevalence of a mutation in the factor $\mathrm{V}$ gene within the U.K. population: relationship to activated protein $\mathrm{C}$ resistance and familial thrombosis. Br J Haematol 88: 219-222, 1994.

13. Rosendaal FR. Venous thrombosis: a multicausal disease. Lancet 353: $1167-1173,1999$

14. Emmerich J, Rosendaal FR, Cattaneo M, et al. Combined effect of factor V Leiden and prothrombin 20210A on the risk of venous thromboembolism: pooled analysis of 8 case-control studies including 2310 cases and 3204 controls: Study group for pooledanalysis in venous thromboembolism. Thromb Haemost 86: 809816, 2001.

15. Gul A, Ozbek U, Ozturk C, Inanc M, Konice M, Ozcelik T. Coagulation factor $\mathrm{V}$ gene mutation increases the risk of venous thrombosis in behçet's disease. Br J Rheumatol 35: 1178-1180, 1996.

16. Rosendaal FR, Doggen CJ, Zivelin A, et al. Geographic distribution of the $20210 \mathrm{G}$ to A prothrombin variant. Thromb Haemost 79: 706-708, 1998.

17. Akar N, Misirlioglu M, Akar E, Avcu F, Yalçin A, Sözööz A. Prothrombin gene 20210 G-A mutation in the Turkish population. Am J Hematol 58: 249, 1998.

18. Frosst $\mathrm{P}$, Blom HJ, Milos R, et al. A candidate genetic risk factor for vascular disease: a common mutation in methylenetetrahydrofolate reductase. Nat Genet 10: 111-113, 1995.

19. Sotiriadis A, Vartholomatos G, Pavlou M, et al. Combined thrombophilic mutations in women with unexplained recurrent miscarriage. Am J Reprod Immunol 57: 133-141, 2007.

20. Juul K, Tybjaerg-Hansen A, Steffensen R, Kofoed S, Jensen G, Nordestgaard BG. Factor V Leiden: The Copenhagen City Heart Study and 2 metaanalyses. Blood 100: 3-10, 2002.

21. Kim RJ, Becker RC. Association between factor V Leiden, prothrombin G20210A, and methylenetetrahydrofolate reductase C677T mutations and events of the arterial circulatory system: a meta-analysis of published studies. Am Heart J 146: 948-957, 2003.

22. Mueller T, Marschon R, Dieplinger B, et al. Factor V Leiden, prothrombin G20210A, and methylenetetrahydrofolate reductase C677T mutations are not associated with chronic limb ischemia: the Linz Peripheral Arterial Disease (LIPAD) study. J Vasc Surg 41: 808-815, 2005.

23. Jensen R. Clinical presentation of arterial thrombosis vs. venous thrombosis. Clin Hemost 8: 1-6, 2002.

(C) 2011 The Japanese Society of Internal Medicine

http://www.naika.or.jp/imindex.html 